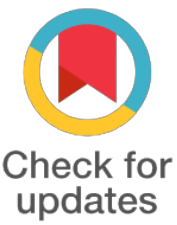

updates
*For correspondence:

kimbasx@gmail.com

Competing interests: The authors declare that no competing interests exist.

Received: 2017-06-14 Accepted: 2017-07-02

Published: 2017-09-05

Copyright The Author(s) 2017. This article is published with open access by BioMedPress (BMP).

This article is distributed under the terms of the Creative Commons Attribution License (CC-BY 4.0) which permits any use, distribution, and reproduction in any medium, provided the original author(s) and the source are credited.

\section{Reconstruction of the major defects of the tissue scalp}

\author{
M.I. Muradov*, K.B. Mukhamedkerim, A.ABaiguzeva, K.E. Kazantaev, \\ D.Zh. Koshkarbaev.
}

National Scientific Center of Surgery named after A.N. Syzganov, Almaty, Republic of Kazakhstan.

Reconstructive, plastic and aesthetic microsurgery department.

\section{Abstract}

Background: To provide quantitative objective data demonstrating the longevity and amount of volume augmentation in the fatty dystrophy of the facial tissue obtained with autologous lipofilling.

Methods: In our clinic had been operated 8 patients for last 2 years with fatty dystrophy of the facial tissue. A prospective analysis of all patients who underwent at our private practice and were followed up for at least 1,5 year. Surgery was performed under general anesthesia it is necessary for clear results tissue correction. We based on the literature has seen numerous clinical reports highlighting the benefits of autologous fat transfer for face from that areas, fat was collected from the abdomen (most frequently used donor site), hips, outer thighs (saddlebags), internal knee or thigh, with quantitative volume measurements evaluating the amount of postoperative volume change.

Results: Twenty eight patients were included in the study. The mean follow-up time was 18 months. The mean amount of autologous fat injected into each face region was 10-70 $\mathrm{mL}$. Hypercorrection was performed after 3 months and it was $20-50 \%$ of the initial injected fat volume. Overall, the mean absolute volume augmentation measured at their last (after 6 month) post operative visit was $10-25 \%$. There was variability between patients in the volume amount and percentage that remained. The resorption process was observed in two patients after 6 month. We made correction with hyaluronic acid and silicone implants.

Conclusion: To our knowledge, this study is the first clinical quantification in our practise of autologous fat transfer and/or grafting in the literature that provides definitive evidence on the amount as well as the resultant longevity in the face. Autologous fat transfer to the face has definite long-term volume augmentation results. On average, approximately $25-35 \%$ of the injected volume remains at 18 months. However, some variability exists in the percentage of volume that remains that may require a touch-up procedure.

\section{Keywords}

Lipofilling, fatty dystrophy, facial tissue. 


\section{Funding}

\section{References}

1. Calabria R Fat grafting: fact or fiction? Aesthetic Surg J 2005; 25 (1) 55 Article

2. Carraway JH, Mellow CG (1990) Syringe aspiration and fat concentration: a simple technique for autologous fat injection. Ann Plast Surg 24: 293-296.

3. Coleman SR (2001) Structural fat grafts: the ideal filler? Clin Plast Surg 28: 111-119.

4. Guerrerosantos J (2000) Long-term outcome of autologous fat transplantation in aesthetic facial recontouring: sixteen years of experience with 1936 cases. Clin Plast Surg 27: 515-543.

5. Coleman SR Long-term survival of fat transplants: controlled demonstrations. Aesthetic Plast Surg 1995;19 (5) 421- 425 